\title{
PENGARUH GREEN BRAND POSITIONING, GREEN BRAND ATTITUDE, GREEN BRAND KNOWLEDGE TERHADAP GREEN PURCHASE INTENTION
}

\author{
Evan Himawan \\ Program Studi Magister Manajemen Universitas Tarumanagara \\ Christevan23@gmail.com
}

\begin{abstract}
The purpose of this paper is to explore the direct and indirect influence of green brand positioning, green brand attitude and green brand knowledge on green purchase intention. Data were collected from 199 respondents. "green brand positioning" measure used five-item scale, "green brand attitude" measured used six-item scale, "green brand knowledge" and "green purchase intention" measure used five-item scale. All measurement items were measured on five point Linkert-type scales. The three hypotheses in this paper have been tested. green brand positioning significantly gives positive influence to green purchase intention. Green brand attitude significantly gives positive influence to green purchase intention and green brand knowledge significantly gives positive influence to green purchase intention.
\end{abstract}

Abstrak : Tujuan dari penelitian ini adalah untuk mengeksplorasi pengaruh langsung dan tidak langsung dari green brand positioning, green brand attitude and green brand knowledge pada green purchase intention. Data dikumpulkan dari 199 responden. "green brand positioning" diukur menggunakan skala lima-item, "green brand attitude" diukur menggunakan skala enam-item, "green brand knowledge" and "green purchase intention" ukuran yang digunakan skala lima-item. Semua item pengukuran diukur pada skala lima titik Linkert-type. Tiga hipotesis dalam makalah ini telah diuji. Green brand positioning secara signifikan memberikan pengaruh positif terhadap green purchase intention. Green brand attitude secara signifikan memberikan pengaruh positif terhadap green purchase intention dan green brand knowledge secara signifikan memberikan pengaruh positif terhadap green purchase intention.

Keywords: Green Purchase Positioning, Green Purchase Attitude, Green Purchase Knowledge, Green Purchase Intention

\section{PENDAHULUAN}

Belakangan ini penyakit seakan-akan menjadi sesuatu yang tidak dapat dipisahkan dari kehidupan manusia diantaranya yang paling banyak diderita adalah cancer, jantung, hepatitis, tuberculosis, diabetes, Vector Borne, dan AIDS dan salah satu penyebab kematian terbanyak di dunia adalah kanker. mayoritas penyebabnya adalah kurangnya konsumsi sayur dan buah, serta diikuti konsumsi garam berlebih dan konsumsi lemak yang berlebihan, untuk mencukupkan konsumsi buah dan sayur maka diciptakannya lah minuman kesehatan yang berbahan dasar buah dan sayur alami.

Menurut Kotler dan Keller (2016) purchase intention adalah sikap konsumen yang ada, sebagai respon dari terhadap suatu objek yang menunjukan minat pelanggan dalam suatu pembelian. Dalam hal ini Chen \& Chang (2012) mengatkan bahwa green purchase intention adalah konsumen kemungkinan besar akan membeli suatu produk tertentu dikarenakan kepedulian mereka karena lingkungan. Penelitian ini juga ingin membandingkan hasil anatara penelitian yang dilakukan oleh peneliti sebelumnya yakni Suki (2016) untuk mengetahui dalam meneliti green purchase intention mana yang lebih berpengaruh signifikan antara variabel green brand positioning, green brand attitude and green brand knowledge. 


\section{TINJAUAN PUSTAKA}

\section{Green Brand Positioning}

Menurut Gwin dan Gwin (2003) menyatakan bahwa green brand positioning adalah untuk menghasilkan keunggulan kompetitif dalam pikiran konsumen atas merek pesaing lainnya berdasarkan atribut produk yang nyata atau tidak berwujud, selanjutnya menurut Aaker and Joachimsthaler (2012) menyatakan bahwa green brand positioning terkait dengan nilai produk atau layanan hijau, yang didasarkan pada atribut ramah lingkungan dari merek yang memiliki arti penting bagi pelanggan.

\section{Green Brand Attitude}

Menurut Sutisna (2002) mengatakan bahwa brand attitude sebagai sikap positif terhadap merek tertentu akan memungkinkan konsumen melakukan pembelian terhadap merek tersebut, sebaliknya jika negatif akan menghalangi konsumen tersebut untuk melakukan pembelian. Pendapat tersebut sesuai dengan Schiffman dan Wisenblit (2015) yang menyatakan perasaan dan sikap positif adalah dampak mendasar yang membentuk sikap pelanggan dan memengaruhi niat mereka untuk membeli suatu produk.

\section{Green Brand Knowledge}

Menurut Kotler dan keller (2016) menyatakan bahwa brand knowledge dapat mengukur sebarapa kenalnya konsumen dengan brand tersebut. Menurut Lawu (2014) "brand knowledge merujuk pada dua istilah yaitu adalah brand awareness \& brand image", pengertian ini selaras dengan Setyawati \& Rochmah (2015) "Brand awareness adalah kemampuan konsumen mengingat atau mengenali sebuah merek sedangkan brand image merupakan representasi penilaian dari konsumen, baik konsumen yang potensial maupun konsumen yang kecewa.

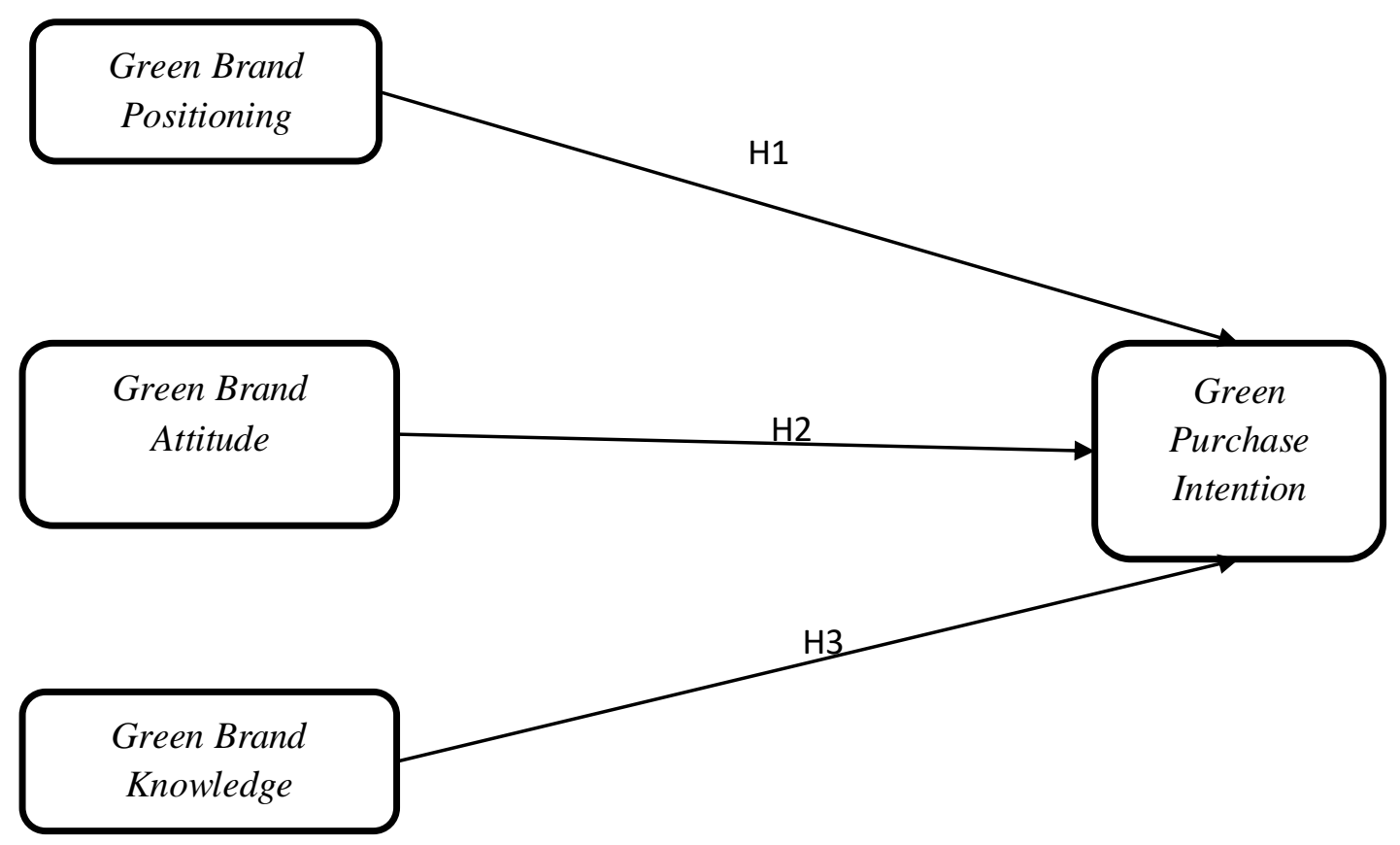

Gambar 1. Model Penelitian

PENGEMBANGAN HIPOTESIS

Kaitan antara green brand positioning dan green purchase intention 
Suki (2016) menyatakan bahwa green brand positioning memberikan dampak positif terhadap green purchase intention. Wati dan Ekawati (2016) mengatakan bahwa green brand positioning memberikan dampak positif terhadap green purchase intention. Utamaputharan dan Amin (2013) menyatakan bahwa green brand positioning memiliki pengaruh positif terhadap green purchase intention. Berdasarkan uraian di atas, maka hipotesis penelitian adalah:

H1 : Green brand positioning berpengaruh terhadap green purchase intention

\section{Kaitan antara green brand attitude dan green purchase intention}

Suki (2016) menyatakan bahwa green brand attitude memberikan dampak positif terhadap green purchase intention. Aulina dan Yuliati (2017) menyatakan bahwa green brand attitude memberikan dampak positif terhadap green purchase intention. Wati dan Ekawati (2016) menyatakan bahwa green brand attitude dampak positif terhadap green purchase intention. Berdasarkan uraian di atas, maka hipotesis penelitian adalah:

$\mathrm{H} 2$ : Green brand attitude berpengaruh terhadap green purchase intention

\section{Kaitan antara green brand knowledge dan green purchase intention}

Suki (2016) menyatakan bahwa green brand knowledge memberikan dampak positif terhadap green purchase intention. Aulina dan Yuliati (2017) menyatakan bahwa green brand knowledge memberikan dampak positif terhadap green purchase intention. Rochmah dan Setyawati (2015) mengatakan bahwa green brand knowledge memberikan dampak positif terhadap green purchase intention. Berdasarkan uraian di atas, maka hipotesis penelitian adalah:

H3 : Green brand knowledge berpengaruh terhadap green purchase intention

\section{METODOLOGI PENELITIAN}

Penelitian kuantitatif dipilih sebagai metode penelitian. Populasi yang digunakan adalah para konsumen yang pernah mengkonsumsi salah satu minuman kesehatan dengan rentang usia 18 - 50 tahun di Jakarta. Metode non - sampling, lebih tepatnya convenience sampling digunakan sebagai metode pengambilan sampel karena metode ini membiarkan peneliti untuk mendekati responden secara acak dengan mudah. Peneliti menggunakan 199 kuesioner sebagai ukuran sampel.

Untuk mengukur variabel penelitian, beberapa instrumen diadaptasi dari penelitian terdahulu. Skala pengukuran (kecuali profil responden) diukur menggunakan skala Likert lima poin dengan 1 menunjukan "sangat tidak setuju", dan 5 menunjukan "sangat setuju". Tabel 1 menunjukan pengukuran masing masing variabel dan sumbernya. Hasil jawaban kuesioner diolah dan diuji reliabilitas dan validitasnya menggunakan model pengukuran. Setelah melewati tahap uji reliabiltas dan validitas, 199 data valid tersebut dianalisa menggunakan uji $\mathrm{f}$ dan uji $\mathrm{t}$. Uji f dan uji t adalah untuk menguji hubungan antara variabel laten independen dan dependen. Dalam penelitian ini terdapat 3 variabel independent yaitu green brand positioning (X1), green brand attitude (X2), green brand knowledge(X3) dengan variabel dependen yaitu green purchase intention $(\mathrm{Y})$.

Tabel 1. Variabel dan Pengukuran

\begin{tabular}{|l|c|l|}
\hline \multicolumn{1}{|c|}{ Variabel } & Item & \multicolumn{1}{c|}{ Sumber } \\
\hline Green Brand Positioning (X1) & 5 & Norazah Mohd Suki (2016) \\
\hline Green Brand Attitude (X2) & 6 & Norazah Mohd Suki (2016) \\
\hline Green Brand Knowledge (X3) & 5 & $\begin{array}{l}\text { Suki (2016) dan Sumarno et } \\
\text { al., (2016) }\end{array}$ \\
\hline Green Purchase Intention (Y) & 5 & $\begin{array}{l}\text { Suki (2016) dan Sumarno et } \\
\text { al., (2016) }\end{array}$ \\
\hline
\end{tabular}




\section{HASIL \& PEMBAHASAN}

Pertama peneliti melakukan uji validita dalam penelitian ini, dengan menggunakan uji Pearson correlation. Dari hasil uji validitas yang dilakukan, dapat dipastikan bahwa semua variabel memiliki indikator yang valid. Setelah melakukan uji validitas peneliti melanjutkan dengan melanjutkan uji reliabilitas, variabel dinyatakan reliabel apabila pernyataan memiliki nilai Cronbach's Alpha > 0,6. Dari hasil uji reliabilitas yang dilakukan dapat dipastikan bahwa semua variabel dinyatakan reliabel.Selanjutnya peneliti melakukan uji asumsi klasik yaitu uji multikolinearitas, uji heterokedastisitas dan uji normalitas dan dari hasil uji tersebut dapat dipastikan bahwa tidak terjadi multikolinearitas dan heterokedastisitas dan juga Residual terdistribusi secara normal. Dari hasil uji $\mathrm{F}$ dapat diperoleh tingkat signifikan sebesar 0.000, dimana angka angka tersebut lebih kecil dari 0.05 dan $\mathrm{H}_{0}$ ditolak. Hal ini berarti terdapat pengaruh variabel green brand positioning, green brand attitude, green brand knowledge secara simultan terhadap purchase intention

Tabel 2. Hasil Uji t

\begin{tabular}{|l|c|c|c|}
\hline Hubungan & T Statistics & P Values & Keterangan \\
\hline $\begin{array}{l}\text { Green brand positioning -> } \\
\text { green purchase intention }\end{array}$ & 3.315 & 0.001 & Signifikan \\
\hline $\begin{array}{l}\text { Green brand attitude -> green } \\
\text { purchase intention }\end{array}$ & 6.087 & 0 & Signifikan \\
\hline $\begin{array}{l}\text { Green brand knowledge -> green } \\
\text { purchase intention }\end{array}$ & 8.650 & 0 & Signifikan \\
\hline
\end{tabular}

Sumber: Data primer yang diolah (2018)

Bedasarkan tabel 2 di atas hasil pengujian green brand positioning terhadap purchase intenton memiliki nilai t sebesar 3,315 serta nilai sig 0,001. Nilai t hitung diatas lebih kecil dibandingkan dengan nilai t tabel sebesar 1,972 dan nilai sig dibawah 0,05 yang menunjukan bahwa green brand positioning tersebut berpengaruh positif dan signifikan terhadap green purchase intention. Hasil ini sesuai dengan penelitian sebelumnya Suki (2016), Wati dan Ekawati (2016), Uthamaputharan dan Amin (2013), Aulina dan Yuliati (2017). Suki (2016) menyatakan bahwa jika konsumen sudah memiliki suatu posisi yang tinggi akan suatu produk maka hal ini dapat dilihat sebagai keuntungan bagi pemasar untuk membedakan produk mereka dari pesaing yang tersedia, memberikan kesan dapat dibedakan, sekaligus menciptakan lebih banyak permintaan dan meningkatkan niat konsumen untuk membeli lebih banyak produk ramah lingkungan. Artinya jika semakin tinggi positioning terhadap suatu brand dalam benak konsumen maka artinya adalah konsumen mengetahui keunggulan suatu produk dibandingkan dengan produk lainnya yang akan membuat keinginan konsumen untuk membeli produk tersebut akan lebih tinggi.

Hasil pengujian green brand attitude terhadap purchase intenton memiliki nilai $\mathrm{t}$ sebesar 6,087 serta nilai sig 0,000. Nilai t hitung diatas lebih kecil dibandingkan dengan nilai t tabel sebesar 1,972 dan nilai sig dibawah 0,05 yang menunjukan bahwa green brand attitude tersebut berpengaruh positif dan signifikan terhadap green purchase intention. Hasil ini selaras dengan Suki (2016), Wati dan Ekawati (2016), Aulina dan Yuliati (2017) yang menunjukan bahwa semakin tinggi sikap konsumen pada green brand attitude terhadap salah satu produk minuman kesehatan maka akan semakin tinggi juga green purchase intention pada produk tersebut. Menurut Utamaputharan dan Amin (2013:355), green product and brand positioning dibagi dua menjadi functional attributes dan emotional benefits dimana 
perasaan akan preferensi akan produk produk ramah lingkungan sangat memiliki pengaruh terhadap minat beli, temuan ini sejalan dengan Wati dan Ekawati (2016) menyatakan keputusan pembelian konsumen seringkali didasarkan pada sikap mereka terhadap lingkungan mereka. Artinya jika seseorang memiliki sikap bertanggung jawab terhadap lingkungan alam maka akan mempengaruhi sikap mereka dalam minat beli green brand.

Hasil pengujian green brand knowledge terhadap purchase intenton memiliki nilai $\mathrm{t}$ sebesar 8,650 serta nilai sig 0,000. Nilai t hitung diatas lebih kecil dibandingkan dengan nilai t tabel sebesar 1,972 dan nilai sig dibawah 0,05 yang menunjukan bahwa green brand knowledge tersebut berpengaruh positif dan signifikan terhadap green purchase intention. Suki (2016), Aulina dan Yuliati (2017) dan Rochmah dan Setyawati (2015) yang menyatakan bahwa semakin tinggi pengetahuan konsumen akan green brand knowledge terhadap salah satu produk minuman kesehatan, maka akan semakin tinggi juga green purchase intention terhadap salah satu produk minuman kesehatan tersebut. Temuan ini selaras dengan Uthamaputharan dan Amin (2013) yang menyatakan bahwa pengetahuan akan green brand yang tinggi akan membuat konsumen lebih sadar akan kualitas dari green product itu sendiri. Hal ini selaras dengan Suki (2016) yang menyatakan bahwa memiliki pengetahuan akan green brand yang tinggi akan meningkatkan juga perhatian khusus akan perlindungan lingkungan dalam membuat suatu produk, artinya jika konsumen memiliki pengetahuan yang baik akan green product maka konsumen akan mengetahui kebaikan kebaikan yang akan di dapat jika membeli produk tersebut, terlebih lagi konsumen akan mulai meningkatkan perhatian lebih terhadap lingkungan sekitarnya.

\section{KESIMPULAN DAN SARAN}

Penelitian yang mengacu kepada jurnal Suki (2016) menunjukan hasil green brand positioning berpengaruh positif terhadap green purchase intention, green brand knowledge berpengaruh positif terhadap green purchase intention, green brand attitude berpengaruh positif terhadap green purchase intention. Melalui hasil dari penelitian ini, peneliti ingin memberikan saran terhadap salah satu produk minuman kesehatan untuk memulai menyebarkan informasi informasi keunggulan dari produk lebih lagi dan sesering mungkin hal ini dilakukan guna untuk meningkatkan brand positioning di dalam benak konsumen sehingga konsumen dapat membedakan produk tersebut dengan minuman lainnya, Selain itu perusahaan juga harus memulai untuk meningkatkan kesadaran masyarakan akan kepentingan menjaga lingkungan dan melestarikannya, dengan membuat program program yang membuat konsumen sadar dan memulai mencintai lingkungan dengan cara menggunakan produk produk ramah lingkungan atau green brand, hal ini guna untuk meningkatkan brand attitude hal ini guna untuk meningkatkan brand attitude konsumen sehingga konsumen dapat menyadari betapa baiknya produk tersebut dan yang terakhir perusahaan harus meningkatkan lagi pengetahuan pengetahuan akan bahayanya produk produk yang menggunakan kimia dan juga kebaikan kebaikan dari produk yang memakai bahan alami sehingga konsumen tidak terjebak dengan harga yang murah dan juga rasa yang enak tanpa mementingkan kesehatan mereka, salah satu hal yang dapat dilakukan adalah dengan cara membuat seminar seminar tentang kesehatan atau bahaya dari produk yang menggunakan bahan kimia dan sebagainya, hal ini guna untuk meningkatkan brand knowledge konsumen sehingga konsumen mengerti dengan apa yang ditawarkan kepada mereka, karena konsumen sudah memiliki pengetahuan yang cukup. 


\section{DAFTAR PUSTAKA}

Aaker, D.A. and Joachimsthaler, E. (2002). "Brand leadership". Academy of Marketing Science. Vol. 30 No. 2. 175-178.

Aulina, L., Yuliati, E. (2017). The Effects of Green Brand Positioning, Green Brand Knowledge, and Attitude towards Green Brand on Green Products Purchase Intention, International Conference on Business and Management Research Vol 36, 548 - 557

Chen, Y.S. and Chang, C.H. (2012), "Enhance green purchase intentions: the roles of green perceived value, green perceived risk, and green trust", Management Decision, Vol. 50 No. 3, pp. 502-520.

D’Souza, Clare, et. al. (2006). "Green Product And Corporate Strategy: An Empirical Investigation, Society And Business Review". Emerald Journal, Vol.1, No.2, Hal. 144-157.

Ganapathy, S.P., Natarajan, J., Gunasekaran, A. and Subramanian, N. (2014), "Influence of ecoinnovation on Indian manufacturing sector sustainable performance", International Journal of Sustainable Development and World Ecology. Vol. 21 No. 3. 198-209.

Gwin, C.F. and Gwin, C.R. (2003), "Product attributes model: a tool for evaluating brand positioning". Journal of Marketing Theory and Practice. Vol. 11 No. 2. 30-42.

Kotler, Philip, and Kevin Lane Keller. 2016. Marketing Management. Upper Saddle River, N.J.: Pearson Prentice Hall.

Lawu, Bakti, J. (2015). "Pengaruh Elemen Brand Knowledge Dan Brand Equity Terhadap Repurchase Intention”. Jurnal Manajemen. Vol.14, No. 2. 197 - 222

Schiffman, L.G. and Wisenblit, J. (2014). Consumer Behaviour. 11th ed. Pearson Education Inc.,Essex, NJ.

Setyawati, Chandra., Rochmah, Nurul Rochmah. (2015). "Pengaruh brand knowledge terhadap pemilihan rumah sakit" Jurnal Administrasi Kesehatan Indonesia. Vol. 3 Nomor 1 Januari-Juni 2015. 31 - 39

Suki, Mohd Norazah. 2016. "Green product purchase intention: impact of green brands, attitude, and knowledge" Malaysia. British Food Journal. Vol. 118 Iss 12 pp. 2893 2910.

Sutisna. 2002. Perilaku Konsumen dan Komunikasi Pemasaran. Bandung: Penerbit PT. Remaja Rosdakarya.

Sumarno., Soesanto, Harry., Sufian, Syuhada. (2016). "Studi Mengenai Keputusan Pembelian Dengan Pendekatan Service Encounter, Service Convenience Dan Product Knowledge Yang Dimediasi Oleh Purchase Intention Pada Bengkel Pt. Astra International-Daihatsu Sales Operation Semarang". Jurnal Sains Pemasaran Indonesia. Vol XV. No. 2.93-106.

Uthamaputharan, S., Amin, M., 2013. "Green Product Positioning and Purchase Intention in Malaysia”. In Diversity, Technology, and Innovation for Operational Competitiveness: Proceedings of the 2013 International Conference on Technology Innovation and Industrial Management. Wen, T.C., Noor, N.A.M., 2015.

Wati, Dewa Ayu Sri Pradnya., Ekawati, Ni Wayan. 2016. "Pengaruh green brand positioning terhadap niat pembelian dimediasi oleh sikap". E-Jurnal Manajemen Unud. Vol. 5 No.

10.

6731-6761. 
